Academic City University College - Accra Ghana

Society for Multidisciplinary \& Advanced Research Techniques (SMART) Africa

Tony Blair Institute for Global Change

FAIR Forward - Artificial Intelligence for All - Deutsche Gesellschaft für Internationale Zusammenarbeit (GIZ) GmbH

Accra Bespoke Multidisciplinary Innovations Conference (ABMIC)

\title{
The Combined Culturo-Techno-Contextual Approach (CTCA) and Peer-Led Team Learning (PLTL) Strategies to Teaching and Learning Machine Language in Secondary Schools in Breaking Its Difficulty
}

\section{Michael Adelani Adewusi, Silas Eniola Egbowon, Ife Abodunrin \& Kunle Rahman}

African Centre for Innovative STEM Education (ACEITSE)

Lagos State University, Ojo

E-mail: mikeade3000@yahoo.com

Phone: 0000-0002-8003-6761

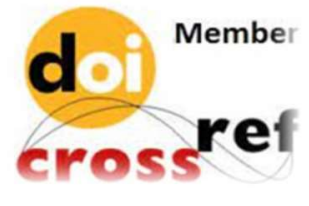

Michael Adelani Adewusi, Silas Eniola Egbowon, Ife Abodunrin \& Kunle Rahman (2021): The Combined Culturo-Techno-Contextual Approach (CTCA) and Peer-Led Team Learning (PLTL) Strategies to Teaching and Learning Machine Language in Secondary Schools in Breaking Its Difficulty. Proceedings of the Accra Bespoke Multidisciplinary Innovations Conference. University of Ghana/Academic City University College, Accra, Ghana. December 2021. Pp 141-154. www.isteams.net/ghanabespoke2021.

DOI https://doi.org/ 10.22624/AIMS/ABMIC2021-V2-P11 


\title{
The Combined Culturo-Techno-Contextual Approach (CTCA) and Peer-Led Team Learning (PLTL) Strategies to Teaching and Learning Machine Language in Secondary Schools in Breaking Its Difficulty
}

\author{
Michael Adelani Adewusi, Silas Eniola Egbowon, Ife Abodunrin \& Kunle Rahman
}

\begin{abstract}
There have been several efforts and interventions through research and workshops to introduce novel interventions in teaching and learning strategies by science educators around the globe. And countless numbers of strategies to improve academic performance had been introduced in the learning environment. However, many factors could be linked to different academic achievement and attitude to teaching and learning. Therefore, this study was conducted to investigate if the use of Culturo-TechnoContextual Approach (CTCA), a learning strategy that incorporate the use of cultural knowledge (indigenous knowledge), component of contextual drawing from the immediate environment to illustrate teaching, and the component of technology to better strengthen learning. And the Peer-Led Team Learning (PLTL), a strategy involving peer learning method interventions to enhance the academic achievement and attitude of students in senior school in machine language. Why machine language? It is a concept in the Nigeria computer studies curriculum that students find difficult to learning. It is hypothesized that there is no statistically significances difference in i) effects of class stream (science, commercial, and arts) in achievement and attitude, and ii) in school type (private and public) in achievement and attitude when taught using the two strategies to teaching and learning machine language in secondary school. The research design was quasi-experimental (a pre-test post-test nonequivalent group) design. A total of 207 computer studies students in senior secondary year two (SS2) comprising 106 females and 101 males participated in the study. The instrument used to gather data was the machine language attitudes questionnaire (MLAQ) and machine language achievement test (MLAT) which had a reliability coefficient of 0.65 . There are two experimental groups and they were taught separately with CTCA and PLTL while the control group was taught with the traditional lecture method. The data (pre-test and post-test scores) collected were analysed using mancova since the participants were not randomly assigned to the groups. When CTCA is used, students are required to (a) draw on their topicrelevant indigenous (cultural) knowledge; (b) use technology to seek pre-lesson knowledge of the topic to be taught; (c) work in groups to share knowledge gleaned from their socio-cultural interactions and webbased resources; and (d) draw on their prior knowledge of the topic when used. While the PLTL is based on social dimension, scientific learning discovery, and optimal learning which is active engagement by the students. The study found no statistically significant effect of class stream of students on achievement and attitudes of students when taught using CTCA, PLTL or lecture method $[F(2,202)=0.20 ; p>0.05]$ and on attitude $[F(2,202)=2.13 ; p>0.05]$. While there was a significant difference in machine learning achievement of students taught using CTCA, PLTL, and the Lecture method $[F(1,203)=4.34 ; p<.05]$ and a significant different in school type in machine learning attitude of students taught using CTCA, PLTL, and the Lecture method. $[F(1,203)=5.82 ; p<.05]$. Hence, the study concluded that educators are encouraged to use the CTCA and PLTL and they could capitalise on the assets of the CTCA and PLTL in demonstrating how it could be employed as a pedagogical design for enhancing the achievement and attitude of students in computer studies and other subjects which are offered at the senior secondary schools. The strategies will help both teachers and students to gain respect for local activities and culture, its wisdom and ethics and appreciate indigenous science and technology and appreciate the use of local resources more thereby enhancing sustainability and it will encourage collaboration among students thereby leading to better academic achievement and attitude.
\end{abstract}

Keyword: Culturo-Techno-Contextual Approach (CTCA); Peer-Led Team Learning (PLTL); Machine Language; Collaborative. 


\section{INTRODUCTION}

Education, as the leading and most critical institution in society, has gradually been lost in Nigeria with the continuous us of traditional method of teaching and learning. The earlier conception that the educational system produces excellence in identifying and developing an individual promise by means of academic achievement is now a mirage. In 1982, it established and implemented the first National Education Policy. Since then, there have been some improvements and adjustments at different levels of the education system (Adeleye, Luiz, Muthuri, \& Amaeshi, 2020; Raimi, Suleiman, Odipe, Tolulope, Modupe, Olalekan, \& Christianah, 2019; Mabuza, 2018; Otukile-Mongwaketse \& Tshidaho, 2020). However, Ashby (2019) and Gunter (2018) identified and recommended an enriched curriculum to ensure students' relevance to their local manpower development. This had not been followed in most secondary learning institutions of academy but were continuing with the conventional method.

It is therefore essential to attend to the needs of the learners and the varying needs of the whole students by taking the academic system specifications into consideration (Erümit \& Çetin, 2020). This was collaborated by Naeem Atanda Balogun, Fabian Aiterebhe Ehikhamenor, Omenogo Veronica Mejabi, Rafiat Ajibade Oyekunle, Olayiwola Wasiu Bello \& Oluyinka Titilope Afolayan, (2020) that the government to educate, train and implement policies: like implementing teaching and learning strategies that would help make students to perform better in their studies would be of tremendous improvement in academy. Indrasiri and Siriwardena (2018) are thus postulating that education are always changing bringing in newer styles through shifts in technological landscape with the desire of finding acceptable ways of having appreciable, reliable, and efficient way to teach students.

\subsection{Purpose of the Study}

This study is to find out the impact of CTCA, a learning strategy that incorporate the use of cultural knowledge (indigenous knowledge), component of contextual, drawing from the immediate environment to illustrate teaching, and the component of technology to better strengthen learning. And the PLTL, a strategy involving peer learning method, on secondary school students' achievement and attitude to machine language in computer studies. In specific terms, the study was to determine the extent of class stream (science, commercial or art) on their achievement and attitudes when taught through the use of CTCA and PLTL and; to establish the extent at which the students' achievement and students' attitude are enhanced when taught through the strategies in private or public school. There are fewer literature that had reported imparts of learning strategy in terms of class stream and school type.

The study sought to answer the following null research questions: Is there any significant effect of class stream (science, commercial or art) on (a) students' achievement and (b) students' attitudes when taught using CTCA, PLTL or lecture method? And is there any significant effect of school type on (a) students' achievement and (b) students' attitude when taught using CTCA, PLTL or lecture method? Studies have reported findings in term of effects of class placement in academic performances (see Weinstein, Nunes, \& Karpicke, 2016; Caspersen \& Smeby, 2020) but little studies had been conducted to determine if a teaching and learning strategy has effect on same class placement of students but different streams. This is very necessary as it address the issue of the common saying that science students are more knowledgeable to commercial class or arts students. 
The study is also intended to clear the erroneous insinuation that the public school, which is owned by the government is better to private school, which is owned by an individual and visversa by the general public without any scientific backing to the assumption. Machine language is a concept in computer studies curriculum that deals with the teaching and learning computer programming in 0s and $1 \mathrm{~s}$. The bottom line is that machine language is primarily concerned with computer programmes. The entire process begins with data analysis, such as instructions or experience inputs in the computer programming. Furthermore, in the study by Okebukola et al (2019), involving secondary schools drawn from both Ghana and Nigeria having 1,177 computer studies students from nine public and 12 private secondary schools identified machine language as one of the most difficult concept. However, the study did not provide teaching and learning strategy in breaking down the difficult concept but just ranking analysis of identification of difficult concepts in the teaching and learning of computer studies.

In addition, any educational system in operation has a single primary goal: to create a system that has a favorable impact on future generations. The system must be simple to use and complete all duties flawlessly. Machine language in secondary school system is to prepare students with the complete knowledge of computing devices (see Baron, Drot-Delange, Grandbastien, \& Tort, 2014) which is significant in this $21^{\text {st }}$ century era of artificial intelligence, internet of things, block chain technology and so on.

\section{METHODOLOGY}

The study employed a mixed methods. The use of the quantitative and qualitative approaches in combination or all together in order to provides a better understanding of research problems and or complex phenomena than either approach alone (Jaiyeole, 2020). The target population of the study is 207 senior secondary school two students in Lagos State drawn from both public and private secondary schools.

First the study employed the conduct of pre-tests (achievement and attitude) to understand the entry level of the students, eliciting both achievement and attitude information from the students regarding how they perceive and perform academically from the topics or concepts of machine language. Further, the treatments (CTCA and PLTL) was implemented for the experimental groups while the control were taught with the conventional lecture method. The treatments lasted for three weeks: the CTCA group had 45 minutes of contact with the teacher every week covering three topics; the PLTL group had an average of 60 minutes of contact with their team led (a team of 10 students of seven groups) every week covering same three topics.

Prior to the implementation of the PLTL strategy, seven students in higher class that had excellent grades in computer studies were taken through a two-week training programme on the implementation of the PLTL. The control group were taught with the normal conventional lecture method. Three lessons were held over the weekends, and were posttests. The administration of the tests was carried out with care with no observable differences in the process, especially for the groups in terms of the time allocated, the supervisor and the willingness of the students to take the tests. The classroom environment was free from distractions, boredom and fatigue in other to improve tests reliability. The instruments used to gather data were: machine language attitudes questionnaire (MLAQ), having three sections "A", "B", and "C". Section "A" is to gather demographic data of the respondents, section "B" contains 18 question items in a four-point rating scale of: Strongly Disagree (SD), Disagree (D), Agree (A) and, Strongly Agree (SA). 
Section " $C$ " is a quantitative part seeking to know if the student has any further information to give. It was administered as pretest and posttest after the implementation of the treatments to all the groups (two experimental and a control) during the study. And machine language achievement test (MLAT) is having two sections " $A$ ", and " $B$ ". Section " $A$ " is to gather demographic data of the respondents, section "B" contains 30 question items for the students to attempt choosing within options A through D. The MLAT was administered as pretest and posttest after the implementation of the treatments to all the groups (two experimental and a control) during the study.

The instruments were subjected to face validation by three experts; two from the faculty of Education, and one from the faculty of Sciences in the university. The experts looked at the adequacy of the items in line with the research questions as well as the rating scale. Corrections was made. The instruments were been considered valid by the experts for the study. The instrument had a reliability coefficient of 0.65 .

The CTCA involves featuring the culture, technology and context frameworks in the delivery of every lesson. The first step is before the class while the last step is at the conclusion of or after the class. The four walls of the classroom are not limiting boundaries of CTCA.

\section{Steps}

1. Inform students ahead of time of the topic to be learned in class. Ask each student to (a) reflect on indigenous knowledge or cultural practices and beliefs associated with the topic or concept. Students should be made aware that such reflections are to be shared with others in class when the topic is to be taught; and (b) using their mobile phones or other internet-enabled devices, search the web for resources relating to the lesson (first technology flavour of the approach).

2. At the start of the lesson and after the introduction by the teacher, students are grouped into mixedability, mixed-sex groups to share individual reflections on (a) the indigenous knowledge and cultural practices and beliefs associated with the topic; and (b) summaries of ideas obtained from web resources. All such cultural and web-based reflections are documented and presented to the whole class by the group leaders. The teacher wraps up by sharing his/her indigenous knowledge and cultural practices associated with the topic.

3. The teacher progresses the lesson, drawing practical examples from the immediate surroundings of the school. Such examples can be physically observed by students to make science (or any subject) real. This is one of the "context" flavours of the approach. The teacher should sprinkle delivery with some content-specific humour.

4. As the lesson progresses, the class is reminded of the relevance of the indigenous knowledge and cultural practices documented by the groups for meaningful understanding of the concepts. If misconceptions are associated with cultural beliefs, they are cleared by the teacher.

5. At the close of the lesson, the teacher sends a maximum 320-character summary of the lesson (two pages) via SMS or WhatsApp to all students. After the first lesson, student group leaders are to send such messages. This is another of the technology flavours of the approach. 
The frameworks provide a particular perspective, or lens, through which we examine a topic such as CTCA (Durbarry, 2017). There are many different lenses, such as psychological theories, social theories, organisational theories, cultural theories, technology theories and of course several philosophies which may be used to define concepts and explain phenomena such as CTCA.

\subsection{Implementing the Peer-Led Team Learning: A Reference Guide}

Peer-led Team Learning (PLTL), is an integrated training model for a peer-leading classroom. PLTL recruits a student who has already performed well in the course into a peer leader: a student who conducts weekly workshops with six to twelve students for discussion and problemsolving. The PLTL model was created at New York City College for General Chemistry in the early 1990s and became a globally known and reproduced model for STEM training to date (Gosser, 2012).

\subsection{Theories associated with PLTL \\ Scientific Learning and Discovery}

Traditional, lecture-oriented instruction stands in stark contrast to the process of scientific discovery, which builds on prior knowledge but requires vigorous debate and discussion without slavish adherence to authority. Understanding depends on the evidence, our ability to work with models and to build a consensus. Students, however, often work in isolation, and the lecture model does little to change that behavior (Gosser, 2012).

\section{Social Dimension}

PLTL also highlights the deep social character of learning. The concept of effective teaching in the zone of proximal development (Vygotsky, 1987). It is particularly appropriate to the dynamics of PLTL and is described as the gap between the level of effective development as established by independent problem solving, and the level of potential development as determined by it (Gosser, 2012).

\section{Theory of Optimal Learning}

PLTL is based on cognitive science theories that emphasise the importance of facilitated active engagement. The following characteristics have been summarised (Momennejad, Otto, Daw, \& Norman, 2018) as the optimal learning environment:

- Provide a high level of interaction and feedback

- Motivate

- Maintain a constant sense of challenge

- Create a sense of direct engagement

- Provide task-appropriate tools

The PLTL environment has the potential to meet all of these optimal learning characteristics (Gosser, 2012).

\section{Collaborative Learning Techniques}

The goal of implementing collaborative learning strategies is to increase engagement, achieve goals, and enable each group member to participate completely. To get students involved and keep them on track, group assignments can be used in combination with collective learning strategies. To engage students and keep them on board with the lesson goal, group assignments can be used in combination with collective learning strategies. The Peer-Led aims to spark conversation and promote participation without interrupting. 
For any of the various forms of group learning strategies, use guided questioning (Costanza, Lelbrecht, Cooper \& Sanders, 2009).

\section{DATA ANALYSIS AND RESULTS}

The two data sets (comprising the achievement and attitude in pretest and posttest scores) generated during data collection for the study were analysed using IBM SPSS version 25 software. The data for the first research question which sought to investigate if the effect of class stream of students on (a) achievement and (b) attitudes when taught using CTCA, PLTL or lecture method were analysed using analysis of covariance (MANCOVA).

Since an intact class was used and students were not randomised, it was expedient to use mancova to partial out the initial differences between the groups. Having confirmed that the Levene's test of homogeneity of variance $(F=.53 ; P>.05)$ for achievement and $(F=.5 .29 ; P<$ .05) for attitude. The test of Equality of Covariance (Box's M) [F=1.98; P > .05]. The one-way MANCOVA results multivariate $F$ (Pillai's Trace) was not significant $[F=1.14 ; p>0.05]$ univariate on achievement $[F(2,202)=0.20 ; p>0.05]$ and on attitude $[F(2,202)=2.13 ; p>0.05]$ failed to attain a statistical significance (see Table 5).

Table 3: Descriptive Statistics of Training method mean and standard deviation by sex

\begin{tabular}{|l|l|l|l|l|}
\hline & Sex & Mean & Std. Deviation & N \\
\hline Total Achievement Score & MALE & 20.82 & 4.22 & 101 \\
\cline { 2 - 5 } & FEMALE & 20.61 & 3.95 & 106 \\
\cline { 2 - 5 } & Total & 20.72 & 4.08 & 207 \\
\hline Total Attitude Score & MALE & 52.00 & 5.37 & 101 \\
\cline { 2 - 5 } & FEMALE & 52.83 & 5.04 & 106 \\
& Total & 52.43 & 5.21 & 207 \\
\hline
\end{tabular}

Table 4: Descriptive Statistics of Training method mean and standard deviation by class stream

\begin{tabular}{|l|l|l|l|l|}
\hline & Class Stream & Mean & Std. Deviation & N \\
\hline \multirow{5}{*}{ Total Achievement Score } & SCIENCE & 20.60 & 4.23 & 97 \\
\cline { 2 - 5 } & COMMERCIAL & 20.61 & 4.07 & 49 \\
\cline { 2 - 5 } & ARTS & 20.98 & 3.88 & 61 \\
\cline { 2 - 5 } & Total & 20.72 & 4.08 & 207 \\
\hline \multirow{5}{*}{ otal Attitude Score } & SCIENCE & 51.75 & 5.11 & 97 \\
\cline { 2 - 5 } & COMMERCIAL & 52.82 & 3.83 & 49 \\
\cline { 2 - 5 } & ARTS & 53.18 & 6.18 & 61 \\
\cline { 2 - 5 } & Total & 52.43 & 5.21 & 207 \\
\hline
\end{tabular}


Table 5: Analysis of Covariance of total achievement and attitude tests of Class Stream

\begin{tabular}{|c|c|c|c|c|c|c|}
\hline Source & Dependent Variable & $\begin{array}{l}\text { Type III Sum } \\
\text { of Squares }\end{array}$ & $\mathrm{df}$ & $\begin{array}{l}\text { Mean } \\
\text { Square }\end{array}$ & $\mathrm{F}$ & Sig. \\
\hline \multirow[t]{2}{*}{ Corrected Model } & $\begin{array}{l}\text { Total Achievement } \\
\text { Score }\end{array}$ & 16.37 & 4 & 4.09 & .24 & .91 \\
\hline & Total Attitude Score & 239.48 & 4 & 59.87 & 2.26 & .06 \\
\hline \multirow[t]{2}{*}{ Intercept } & $\begin{array}{l}\text { Total Achievement } \\
\text { Score }\end{array}$ & 826.30 & 1 & 826.30 & 48.98 & .00 \\
\hline & Total Attitude Score & 4100.53 & 1 & 4100.53 & 154.85 & .00 \\
\hline \multirow{2}{*}{$\begin{array}{l}\text { Pretest } \\
\text { Achievement } \\
\text { Score }\end{array}$} & $\begin{array}{l}\text { Total Achievement } \\
\text { Score }\end{array}$ & 9.99 & 1 & 9.99 & .59 & .44 \\
\hline & Total Attitude Score & 36.76 & 1 & 36.76 & 1.39 & .24 \\
\hline \multirow[t]{2}{*}{$\begin{array}{l}\text { Pretest Attitude } \\
\text { Score }\end{array}$} & $\begin{array}{l}\text { Total Achievement } \\
\text { Score }\end{array}$ & .09 & 1 & .09 & .01 & .94 \\
\hline & Total Attitude Score & 113.87 & 1 & 113.87 & 4.30 & .04 \\
\hline \multirow[t]{2}{*}{ Class Stream } & $\begin{array}{l}\text { Total Achievement } \\
\text { Score }\end{array}$ & 6.84 & 2 & 3.42 & .20 & .82 \\
\hline & Total Attitude Score & 112.54 & 2 & 56.27 & 2.13 & .12 \\
\hline \multirow[t]{2}{*}{ Error } & $\begin{array}{l}\text { Total Achievement } \\
\text { Score }\end{array}$ & 3407.82 & 202 & 16.87 & & \\
\hline & Total Attitude Score & 5349.12 & 202 & 26.48 & & \\
\hline \multirow[t]{2}{*}{ Total } & $\begin{array}{l}\text { Total Achievement } \\
\text { Score }\end{array}$ & 92250.00 & 207 & & & \\
\hline & Total Attitude Score & 574506.00 & 207 & & & \\
\hline \multirow[t]{2}{*}{ Corrected Total } & $\begin{array}{l}\text { Total Achievement } \\
\text { Score }\end{array}$ & 3424.18 & 206 & & & \\
\hline & Total Attitude Score & 5588.59 & 206 & & & \\
\hline
\end{tabular}

The results in table 4 show that the science students $(M=20.60 ; S D=4.23)$, commercial students ( $M=20.61 ; S D=4.07)$, and Arts students $(M=20.98 ; S D=3.88)$ of Total achievement scores. The science students $(M=51.75 ; S D=5.11)$, commercial students $(M=52.82 ; S D=$ 3.83), and Arts students $(M=53.18 ; S D=6.18)$. To ascertain whether this observed comparable difference is real or attributed to error variance, this result was subjected to inferential testing as shown in table 5.

The result obtained in table 5 shows that at the point of entry for students in the class stream for both the pre-tests in the achievement and attitude, they are not significantly different from one another in terms of achievement and attitude except for pre-test attitude $[F(1,202)=4.30$; $P=.04]$ and after treatments, they all remain insignificantly different. Based on this result, Hypothesis one is not rejected since no statistically significant effect of class stream of students on (a) achievement and (b) attitudes when taught using CTCA, PLTL or lecture method was not attained. 
The hypothesis two

The result in table 6 shows that the public school's total achievement score when taught using the three teaching strategies (CTCA, PLTL, and Conventional) have a mean value of 21.13 and SD of 4.04 which is higher than that of the private school $(M=19.90 ; S D=4.06)$. Also, the public school's total attitude score when taught using the three teaching strategies (CTCA, PLTL, and Conventional) have a mean value of 53.01 and SD of 5.15 which is higher than that of the private school $(M=51.29$; $S D=5.18)$. To ascertain whether this observed comparable difference is real or attributed to error variance, this result was subjected to inferential testing as shown in table 7.

Table 6: Descriptive Statistics of Training method mean and standard deviation by school type

\begin{tabular}{|l|l|l|l|l|}
\hline & School Type & Mean & Std. Deviation & N \\
\hline \multirow{5}{*}{ Total Achievement Score } & PUBLIC & 21.13 & 4.04 & 137 \\
\cline { 2 - 5 } & PRIVATE & 19.90 & 4.06 & 70 \\
\cline { 2 - 5 } & Total & 20.72 & 4.08 & 207 \\
\hline \multirow{3}{*}{ Total Attitude Score } & PUBLIC & 53.01 & 5.15 & 137 \\
\cline { 2 - 5 } & PRIVATE & 51.29 & 5.18 & 70 \\
\cline { 2 - 5 } & Total & 52.43 & 5.21 & 207 \\
\hline
\end{tabular}

Table 7: Analysis of Covariance of total achievement and attitude tests of Class Stream

\begin{tabular}{|c|c|c|c|c|c|c|}
\hline Source & Dependent Variable & $\begin{array}{ll}\text { Type III } \\
\text { Sum of } \\
\text { Squares }\end{array}$ & df & $\begin{array}{l}\text { Mean } \\
\text { Square }\end{array}$ & $\mathrm{F}$ & Sig. \\
\hline \multirow[t]{2}{*}{ Corrected Model } & $\begin{array}{ll}\text { Total } & \text { Achievement } \\
\text { Score } & \end{array}$ & 80.91 & 3 & 26.97 & 1.64 & .18 \\
\hline & Total Attitude Score & 279.08 & 3 & 93.03 & 3.56 & .02 \\
\hline \multirow[t]{2}{*}{ Intercept } & $\begin{array}{l}\text { Total Achievement } \\
\text { Score }\end{array}$ & 828.26 & 1 & 828.26 & 50.29 & .00 \\
\hline & Total Attitude Score & 4228.94 & 1 & 4228.94 & 161.69 & .00 \\
\hline \multirow{2}{*}{$\begin{array}{l}\text { Pretest } \\
\text { Achievement } \\
\text { Score }\end{array}$} & $\begin{array}{l}\text { Total Achievement } \\
\text { Score }\end{array}$ & 10.58 & 1 & 10.58 & .64 & .42 \\
\hline & Total Attitude Score & 43.34 & 1 & 43.34 & 1.66 & .20 \\
\hline \multirow[t]{2}{*}{$\begin{array}{l}\text { Pretest } \\
\text { Score }\end{array}$} & $\begin{array}{l}\text { Total Achievement } \\
\text { Score }\end{array}$ & .04 & 1 & .04 & .00 & .96 \\
\hline & Total Attitude Score & 94.91 & 1 & 94.91 & 3.63 & .06 \\
\hline \multirow[t]{2}{*}{ School Type } & Achievement & 71.39 & 1 & 71.39 & 4.34 & .04 \\
\hline & Total Attitude Score & 152.15 & 1 & 152.15 & 5.82 & .02 \\
\hline \multirow[t]{2}{*}{ Error } & $\begin{array}{l}\text { Total Achievement } \\
\text { Score }\end{array}$ & 3343.27 & 203 & 16.47 & & \\
\hline & Total Attitude Score & 5309.51 & 203 & 26.16 & & \\
\hline \multirow[t]{2}{*}{ Total } & $\begin{array}{l}\text { Total Achievement } \\
\text { Score }\end{array}$ & 92250.00 & 207 & & & \\
\hline & Total Attitude Score & 574506.00 & 207 & & & \\
\hline \multirow[t]{2}{*}{ Corrected Total } & $\begin{array}{l}\text { Total Achievement } \\
\text { Score }\end{array}$ & 3424.18 & 206 & & & \\
\hline & Total Attitude Score & 5588.59 & 206 & & & \\
\hline
\end{tabular}


The result obtained in table 7 shows that at the point of entry for students in the school type for both the pre-tests in the achievement and attitude, they are not significantly different from one another in terms of achievement and attitude but after treatments, they were significantly different. The one-way MANCOVA results showed significant difference in machine learning achievement of students taught using CTCA, PLTL, and the Lecture method. $[F(1,203)=4.34$; $p<.05]$ and a significant different in machine learning attitude of students taught using CTCA, PLTL, and the Lecture method. $[F(1,203)=5.82 ; p<.05]$. Based on this result, Hypothesis two is rejected since there is a statistically significant effect of school type of students on (a) achievement and (b) attitudes when taught using CTCA, PLTL or lecture method.

However, since the result is significant, a post hoc was conducted. Post hoc comparisons using Scheffe test indicated that the mean score (see Table 6 ) of total achievement score for the PUBLIC group $(M=21.13, S D=4.04)$ and PRIVATE $(M=19.90, S D=4.06)$ was statistically significantly different (alpha .04). And the total attitude score for the PUBLIC group $(M=53.01$, $\mathrm{SD}=5.15)$ and PRIVATE $(M=51.29, \mathrm{SD}=5.18)$ was statistically significantly different (alpha .02) table 8.

Table 8: Post hoc test

\begin{tabular}{|l|l|l|l|l|l|}
\hline Dependent Variable & $\begin{array}{l}\text { (I) School } \\
\text { Type }\end{array}$ & $\begin{array}{l}\text { (J) School } \\
\text { Type }\end{array}$ & $\begin{array}{l}\text { Mean } \\
\text { Difference (I- } \\
\text { J) }\end{array}$ & $\begin{array}{l}\text { Std. } \\
\text { Error }\end{array}$ & Sig. \\
\hline \multirow{2}{*}{ Total Achievement Score } & PUBLIC & PRIVATE & 1.23 & .59 & .04 \\
\cline { 2 - 7 } & PRIVATE & PUBLIC & -1.23 & .59 & .04 \\
\hline \multirow{2}{*}{ Total Attitude Score } & PUBLIC & PRIVATE & 1.72 & .76 & .02 \\
\cline { 2 - 7 } & PRIVATE & PUBLIC & -1.72 & .76 & .02 \\
\hline
\end{tabular}

\section{DISCUSSION OF RESULTS}

Machine language, or machine code, is a low-level language consisting of binary digits (ones and zeros). High-level languages, such as Swift and C ++, must be compiled into machine language before the code can be executed on a computer. Since computers are digital devices, they only recognize binary data. Every program, video, image, and text character is represented in binary. This binary data, or machine code, is processed by the CPU as input. The resulting output is sent to the operating system or an application, which displays the data visually. For example, the ASCII value for the letter "A" in the machine code is 01000001 , but this data is displayed on the screen as "A". An image can contain thousands or even millions of binary values that determine the color of each pixel. For a program to run correctly, a compiler must compile high-level source code for the correct processor architecture.

For the first research question which is to find if there is a statistical significant different among the class stream when taught using the three methods indicated that there is no statistically significant different meaning that the three methods has nothing to do with student's class placement in either the public or the private school when the three strategies were implemented in the study. This findings was in collaboration to the study of Garon-Carrier, Bégin, Brendgen, Vitaro, Ouellet-Morin, Dionne, and Boivin, (2021), observed that class placement or stream has no significant effect on academy progression of students. The study examined the effects of class stream in a sample of 560 students whose attitude were assessed from ages 5 to 12 years, they found no detrimental effect of class stream among the students. 
Further in a study conducted by Mavilidi, Drew, Morgan, Lubans, Schmidt, and Riley, (2020) shows that there were no differences found in students' attitudes in the class stream. The implication of this was that irrespective of a class stream every students has their unique ability in learning. Teaching and learning strategy is just to assist learners to gain more knowledge and this does not affect which class placement the student is placed to learn. According to (Bellanca, \& Fogarty, 2012; Wentzel, 2020), Science has not been able to uncover all of the subtleties about how learners learn. However, the human brain is made up of several components that, despite providing various roles, work together to ensure that our daily activities run smoothly. The question is: when learning activities is taking place which part(s) of the brain is/are engaged in learning? The cerebral cortex is a speedy answer. This is also the location of the portion of the head that some people scratch when they are looking for solutions to an issue (Okebukola, 2014).

Some studies had reported peer persistence at the beginning of their studies continue to achieve higher grades in subsequent periods. This was collaborated by a study by Hussain, Anwar, and Majoka, (2011) that peer group was more effective for teaching and they achieve higher assessment score. This is due to the nature of the classroom construction, overcrowdedness of students in the class and probably the social interactive of the students. But, more studies need to be conducted basically on this aspect to further find the reason for this occurrence. The hypothesis two was to investigate the effect of school type (private and public) on students' achievement and students' attitude when taught using CTCA, PLTL or lecture method. The result shows a statistically significant different in the use of the strategies, an indication that the strategies were effective in both the public and private schools.

It is worth mentioning here that the result obtained shows that there were no statistically significant difference in the entry levels of the achievement and attitude of the students in both the public and private schools (meaning that the students in both the public and private came in with different entry behaviours) but after the treatments (CTCA, PLTL) there was a significant different in there interaction with the novel teaching strategies. The implemented methods shows that the students' entry behaviours were changed to a positive one.

This findings was in consonant with Mutua, (2014), that a significant main effect on academic achievement was found between types of school in his study. This result implies that there is a 95\% confidence that if students are taught using the CTCA and PLTL in the public and private schools, both their academic performance and attitude will be affected. Several studies had been conducted using either of the strategies (CTCA or PLTL) and their findings are positive but there are limited literature to support the combination of the two novel strategies to investigate its effects on school type.

Furthermore, students gave their experiences as follows:

Student One: I love machine language because it helps me to know more about computer and it gives me more view about the world. Also the teacher taught us with simplicity

Student Two: I like machine language because it is interesting with the way I was taught by not being complex. And because it has proven to be one of those profitable thing in this information age in terms of knowledge, fame and money. I would like to impact the knowledge of computers to people in the nearest future because I enjoyed the teaching 
Student Three: Although, machine language can be easy to understand by knowing the applications and steps. Because it may be interesting

Student Four: Coding is an interesting and innovative way to spend your leisure and I believe I will become a successful web developer/doctor in computer because I was taught well

Student Five: Machine language is an interesting topic that allows student to know more about computer studies and also I like it because it is applicable to many things in the world of technology

\subsection{Ethical Consideration}

At the beginning of the study, the students were informed about the research study's objectives, purpose, and procedure of all the class activities, rules and regulations guiding each groups. Confirming that the students understand the procedure for the research study and acceptance of the terms required for them to fulfill their tasks before commencing the study. More importantly, all students were exposed to all groups' activities done during the course of the research study when the study was completed. Not giving room for any student being disadvantaged at the end of the study.

\section{CONCLUSION AND RECOMMENDATION}

The main aim of the study was to inquire if the CTCA and PLTL strategies in teaching and learning computer concepts such as the machine language would enhance the academic achievement and attitude of students in relative to class stream and school type such that no significant difference would be accounted for. However, no statistical significant different was accounted for in the interaction effect of the class stream both in the achievement and attitude of the students. Though at the pre-test level there was a statistically significant different for their attitude but after the implementation of the teaching methods there was no statistically significant different in the class stream.

Moreover, in the study, there was a statistically significant different in school type (public and private). The students entry levels both at the public and private for both achievement and attitude were not significant but after the administration of the treatments, there was a significant different. Further, a post hoc test was calculated in order to detect which factor is responsible for the significant. After the post hoc analyses, both the public and private schools accounted for the significant.

The position of this study was equally supported by the findings of similar studies conducted within and outside Nigeria. While the intention of this study is not to generalise beyond the population as a result of limitations due to sample size and number of computer concepts treated, we consider it beneficial to offer the following recommendations:. It is hoped that the results of this study will contribute value to computer studies/science teachers and a wide variety of teachers at the secondary school level.

These teachers could capitalise on the assets of the CTCA and PLTL to demonstrate how it could be employed as a pedagogical design for enhancing the achievement and attitude of students in computer studies and other subjects which are offered at the senior secondary schools in Nigeria. 
Secondly, the approach could assist science teachers who are desirous of improving science teaching at secondary school level. Thirdly, educational planners and curriculum developers who decide on syllabuses of secondary schools might wish to consider the results of the study with a view to recommending the CTCA and PLTL as a teaching design in science in our secondary schools. With the result of the successful completion of this study, the benefits accruing from the CTCA and PLTL could be considered as a worthy contribution to the literature in computer studies teaching methods. Furthermore, the integration of indigenous knowledge into computer studies teaching will be significant in the following ways:

1. It will reduce the abstract nature of computer studies concepts and enhance students' understanding and performance in the subject. The concepts will be simplified when indigenous knowledge and practices are integrated and applied;

2. It will help to identify the impact/importance of indigenous knowledge on the effective teaching and teaching of computer studies in senior Secondary School;

3. It will reduce a lot of stress on the teachers both on activities to be carried out and on the collection of instructional materials as some of the students might even explain certain concepts and phenomena better using indigenous knowledge and practices;

4. It will help both teachers and students to gain respect for local activities and culture, its wisdom and ethics and appreciate indigenous science and technology and appreciate the use of local resources.

Conflict of interest/competing interest statement and fund

There are/is no conflict of interest or competing interest and no funding received for this study.

\section{REFERENCES}

1. Adeleye, I., Luiz, J., Muthuri, J., \& Amaeshi, K. (2020). Business ethics in Africa: the role of institutional context, social relevance, and development challenges. Journal of business ethics, 161(4), 717-729.

2. Allotey, G. A. (2019). Ghanaian teachers' beliefs about giftedness and gifted education teaching strategies in mathematics and science (Doctoral dissertation, Queensland University of Technology).

3. Baron, G. L., Drot-Delange, B., Grandbastien, M., \& Tort, F. (2014). Computer science education in French secondary schools: Historical and didactical perspectives. ACM Transactions on Computing Education (TOCE), 14(2), 1-27.

4. Bellanca, J. A., \& Fogarty, R. J. (2012). How to teach thinking skills within the common core: 7 key student proficiencies of the new national standards. Solution Tree Press.

5. Caspersen, J., \& Smeby, J. C. (2020). Placement training and learning outcomes in social work education. Studies in Higher Education, 1-14.

6. Costanza, M. N., Lelbrecht, B. C., Cooper, W., \& Sanders, W. R. (2009). Peer-to-peer training facilitator's guide: Development and evaluation. Northrop Grumman Technical Services Reston VA.

7. Durbarry, R. (2017). Quantitative research. In Research Methods for Tourism Students (pp. 98-113). Routledge.

8. Erümit, A. K., \& Çetin, i. (2020). Design framework of adaptive intelligent tutoring systems. Education and Information Technologies, 25(5), 4477-4500. 
9. Garon-Carrier, G., Bégin, V., Brendgen, M., Vitaro, F., Ouellet-Morin, I., Dionne, G., \& Boivin, M. (2021). Classroom Placement and Twins' Social Behaviors in Elementary School: Providing Empirical Evidence to Inform Educational Policy. Educational Policy, 08959048211015626.

10. Gosser, D. (2012). Department of Education Promising and Practical Strategies to Increase Postsecondary Success: Promising and Practical Strategy: Peer-led Team Learning.

11. Gunter, M. (2018). College in the High School: An Alternative Remediation Model.

12. Hussain, S., Anwar, S., \& Majoka, M. I. (2011). Effect of Peer Group Activity-Based Learning On Students'academic Achievement In Physics At Secondary Level. International Journal of Academic Research, 3(1).

13. Indrasiri, K., \& Siriwardena, P. (2018). Microservices for the Enterprise. Apress, Berkeley.

14. Jaiyeola, E, F. (2020, June 22). Emmanuel Femi Jaiyeola- LASU-ACEITSE Lecture on Conducting Mixed Methods Research. https://youtu.be/13pP9QfLXt8

15. Mabuza, D. C. (2018). Educators' reflections of the Swaziland junior secondary Integrated consumer science curriculum: towards development of a unique content area (Doctoral dissertation).

16. Mavilidi, M. F., Drew, R., Morgan, P. J., Lubans, D. R., Schmidt, M., \& Riley, N. (2020). Effects of different types of classroom physical activity breaks on children's on-task behaviour, academic achievement and cognition. Acta paediatrica, 109(1), 158-165.

17. Momennejad, I., Otto, A. R., Daw, N. D., \& Norman, K. A. (2018). Offline replay supports planning in human reinforcement learning. Elife, 7, e32548.

18. Mutua, M. S. (2014). Academic motivation and self-regulated learning as predictors of academic achievement of students in public secondary schools in Nairobi County, Kenya. Kenyatta University.

19. Naeem Atanda Balogun, Fabian Aiterebhe Ehikhamenor, Omenogo Veronica Mejabi, Rafiat Ajibade Oyekunle, Olayiwola Wasiu Bello \& Oluyinka Titilope Afolayan (2020) Exploring information and communication technology among rural dwellers in sub-Saharan African communities, African Journal of Science, Technology, Innovation and Development, 12:5, 533545, DOI: $10.1080 / 20421338.2019 .1700668$

20. Okebukola, P. A. (2019). The Culturo-Techno-Contextual Approach (CTCA).

21. Okebukola, P. A. O. (2014). Open and Distance Education: A catalyst for production of quality teachers and the transformation of Nigeria. A paper presented at 4th National Teachers Summit held at National Teachers Institute, Kaduna.

22. Otukile-Mongwaketse, M., \& Tshidaho, M. Teacher's Understandings of Implementing Curriculum: A Comparative Study Between Botswana And South African Rural Primary Schools Education System.

23. Raimi, M., Suleiman, R. M., Odipe, O. E., Tolulope, S. J., Modupe, O., Olalekan, A. S., \& Christianah, M. B. (2019). Women role in environmental conservation and development in Nigeria. Ecol Conserv Sci, 1(2).

24. Tinsley, J. D. (1973). The General Introduction of Education about Computers for Primary and Secondary Schools.

25. Vygotsky, L. (1987). Mind in Society. Harvard University Press.

26. Weinstein, Y., Nunes, L. D., \& Karpicke, J. D. (2016). On the placement of practice questions during study. Journal of Experimental Psychology: Applied, 22(1), 72.

27. Wentzel, K. R. (2020). Motivating students to learn. Routledge. 